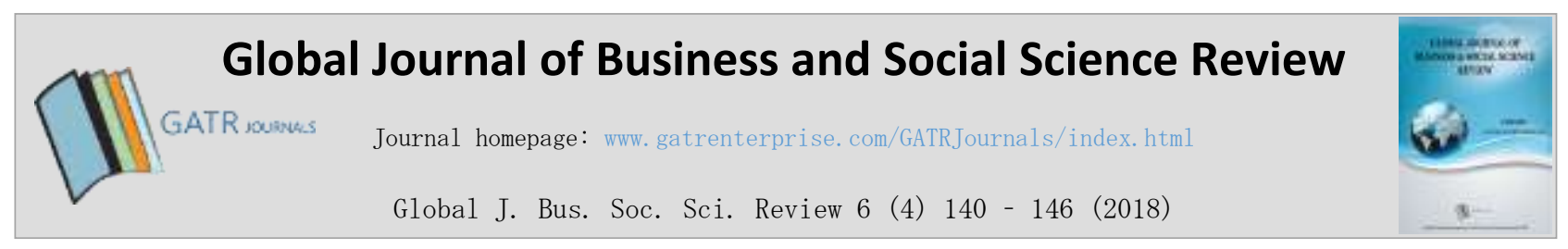

\title{
The Effect of Emotional Branding on Word-Of-Mouth: Evidence from Indonesia
}

\author{
Vita Briliana, ${ }^{\text {a }}$ Nurti Widayati ${ }^{b}$ \\ ${ }^{\mathrm{a}, \mathrm{b}}$ Trisakti School of Management, Jl. Kyai Tapa No. 20 Grogol, West Jakarta, Indonesia
}

\begin{abstract}
Objective - The purpose of this paper is to explore how brand love affects consumers' brand trust, brand loyalty and word-of-mouth promotion towards an online public transport app in Jakarta, Indonesia. GO-JEK is a cost-effective, transport-based application that is used by passengers in Indonesia.

Methodology/Technique - This research uses a purposive sampling technique to select 380 GO-JEK users. Partial least square version 3.0 analysis was used to analyze the data collected through the questionnaires.

Findings - The study reveals that brand love, brand trust and brand loyalty have a positive influence on word-of-mouth advertising.

Novelty - Brand love strongly influences brand trust, followed by brand loyalty and word-of-mouth.

Type of Paper: Empirical.
\end{abstract}

Keywords: Brand Love; Brand Loyalty; Brand Trust; Word-Of-Mouth.

JEL Classification: M30. M31, M39.

\section{Introduction}

In recent years, the use of mobile apps for transportation has gained worldwide popularity. The technology used to develop these services is indirectly influenced by the population in each country. Indonesia has one of the world's largest populations; it is the largest nation in the Southeast Asian region. Jakarta has over 10 million inhabitants, out of a national population of 255 million (Statistics Indonesia, 2017).

The number of transport units in Indonesia is about 104 million, with an estimate of 17.5 million units operating in Jakarta. This capital city is home to 13 million motorcycles and 3.26 million cars. In addition, affordability, efficiency and heavy traffic are some of the factors that make Jakarta one of the most congested cities in the world.

\footnotetext{
* Paper Info: Revised: August 9, 2018

Accepted: December 7, 2018

* Corresponding author: Vita Briliana

E-mail: vita@stietrisakti.ac.id

Affiliation: Trisakti School of Management, Indonesia
} 
PT GO-JEK Indonesia is a limited liability company that provides transportation services such as motorbikes, taxis and courier services. The company was founded by Nadiem Makarim in Jakarta and was established in 2010. GO-JEK's tagline, 'One App for All Your Needs', provides a clear representation of the wide variety of services provided by the company. GO-JEK has become a major competitor to the transportation modes regulated by the local government of Indonesia. The company also offers food delivery services and online payments systems. For instance, users can order a cup of coffee from Starbucks and a motorcyclist will deliver the purchased product. Besides being a homegrown company, GO-JEK is at the early stages of creating an ecosystem, which is similar to that of WeChat in China. In 2015, GO-JEK introduced the use of mobile apps that allow people to order cheap motor taxis in Jakarta. Since then, the company has become a household name in its home country.

Currently, it is Indonesia's largest food shipping business and a leading provider of digital wallets, with 900,000 drivers, and more than 125,000 merchants. Over 100 million transactions are processed through the company's platform monthly. In 2017, GO-JEK outperformed its online transportation competitors by $59.2 \%$, followed by Grab at $28.2 \%$, and Uber at $8 \%$ (http://www.topbrand-award.com, 2017). Moreover, an online publication from liputan 6 which documented the ComScore data of the use of these applications on android devices reveals that GO-JEK had reached 9.7 million users in December 2017. Meanwhile, Grab had 9.6 million users while Uber had over 2 million users. This data shows that the use of GO-JEK for daily activities has gained widespread popularity.

Customers build service expectations through several sources, such as word of mouth, advertisements and past experience. Consumers feel satisfied whenever their customer service experience meets or exceeds their expectations. These consumers are more likely to establish positive emotional ties to a particular brand (i.e. customer loyalty) and recommend the brand to other consumers. Nowadays, consumers use social media platforms (e.g. Instagram) to obtain information about a particular brand and to share their opinions and experiences about certain brands. In addition, consumers may use word of mouth advertisements to share their experience and provide actual recommendations to others about a product. This may influence the decision of other consumers to purchase a product.

The review of existing literature reveals that there is a dearth of information on the influence of brand trust on brand love in the transportation service industry (Carroll \& Ahuvia 2006; Marc, 2014; Anggraeni \& Rachmanita, 2015; Niyomsart et al., 2016; Briliana, 2017; Chao-Chin Huang, 2017; Sabrina et al., 2017). Therefore, there is a need to conduct in-depth research to investigate the gap identified in previous studies. So far, no present study examines the impact of brand love on the decision of consumers to purchase products or services in Indonesia, let alone the Jakarta area. Thus, the purpose of this research is to provide an improved understanding of the impact of brand love (BLV) on brand trust (BTS), brand loyalty (BLO) and word-of-mouth advertising (WOM) of GO-JEK transport app in Jakarta, Indonesia.

\section{Literature Review}

\subsection{Brand Love (BLV)}

Brand love can be described as the emotions felt by passionate consumers due to their satisfaction with the customer service and performance of certain brands (Carroll \& Ahuvia, 2006). A study conducted by Chaudhuri and Holbrook (2002) confirms that there is a strong relationship between brand love and brand loyalty. Briliana (2017) documents that brand love is important in marketing because it is positively associated with brand loyalty. Brand love reflects the extent to which a situation exists when there is a positive emotional bond between consumers and a brand; this may provide huge benefits to the brand. For example, when emotional, consumers are likely to purchase large quantities of goods compared to unemotional customers. In this study, brand love refers to the attitudes of consumers toward a particular brand. This includes their thoughts, feelings and emotions towards the brand. Furthermore, the emotional attachment of consumers to a particular brand affects brand love. 


\subsection{Brand Trust (BTS)}

Azize Sahin et al., (2011) explains that brand trust develops from positive customer experience with a specific brand. The positive beliefs about a consumer's expectation of organizational behavior and product performance influences the development of brand trust. Brand trust is exemplified by the faith of consumers in the promises communicated by the brand owner (Albert et al., 2013). Briliana (2017) reports that brand trust enables a company to increase customer satisfaction and customer retention. In the context of this research, brand trust encompasses the feelings developed by consumers when they assess a brand as well as their image and perception in the form of trust, confidence, security and speed of the services provided.

\subsection{Brand loyalty (BLO)}

Brands that allow consumers to express themselves are able to increase their brand loyalty and positive word-of-mouth advertisement (Carrol \& Ahuvia, 2006). A recent study conducted by Briliana (2017) documents that deliberate brand selection and consumer satisfaction are influenced by the passionate feelings of consumers about certain brands. This may eventually lead to positive word-of-mouth advertisement. Brand loyalty increases a customer's product preferences and decisions to repurchase a particular product (Arjun \& Morris, 2001). In the context of this research, brand loyalty refers to the commitment of consumers to repurchase products or services from the same brand.

\subsection{Word-of-mouth (WOM)}

A study conducted by Niyomsart et al. (2016), which examined the association between brand love, brand loyalty and WOM on passenger aircrafts, shows that there is a positive association between brand love, brand loyalty, and WOM. In the context of this study, WOM occurs when customers are satisfied or impressed with the brand, spread the word about their positive experiences and recommend the product or service to other consumers. Moreover, consumers share their positive and negative experiences via WOM to help facilitate the decision-making processes of other consumers or reduce consumer behavior.

\section{Research Methodology}

\subsection{Conceptual Model}

The SmartPLS 3.0 analysis was selected for this study as it is able to assess all paths simultaneously in order to predict various models and indicators. The reason for using PLS is that it can effectively be used with a relatively small sample size and allows for potentially abnormally distributed data (Hair et al .2017). Figure 1 shows the conceptual framework for this study.

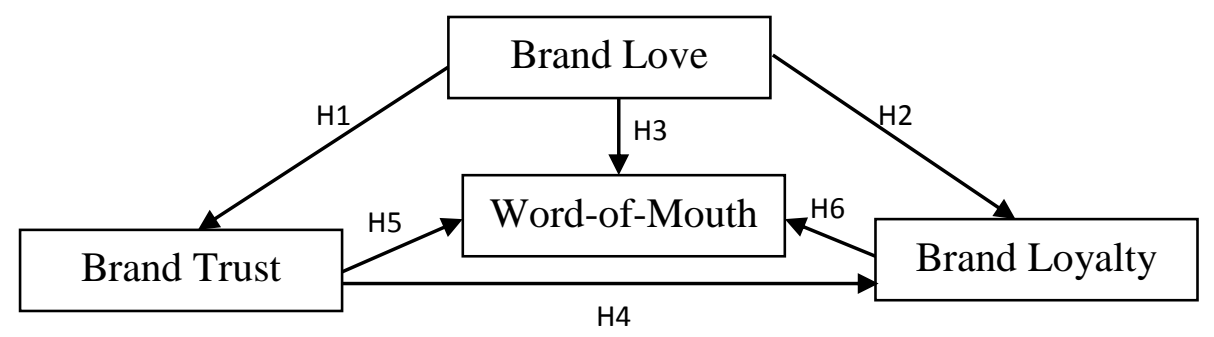

Figure 1 Conceptual Framework 
BLV is proposed as an antecedent of BTS, BLO and WOM in the model; this includes $\mathrm{H} 1, \mathrm{H} 2$, and $\mathrm{H} 3$. Meanwhile, BTS was proposed to have an effect on BLO and WOM, which includes H4 and H5. In addition, BLO was proposed to have an effect on WOM which includes H6.

\subsection{Sample and Data Collection}

An online Google survey was forwarded to respondents via WhatsApp; this means survey distribution enabled the respondents to answer the questions immediately. A total number of 380 completed questionnaires were completed by the respondents. The respondents for the study were selected according to the following pre-set criteria: they often use GO-JEK, they routinely use an online taxi motorbike and they are potential customers of GO-JEK. They also included people who booked through the GO-JEK app with GO-PAY, GO-JEK's electronic payment system and Instagram followers of GO-JEK's official account.

Table 1. Source and number of measurement items pertaining to Brand Love, Brand Loyalty, Brand Trust and Word-ofMouth

\begin{tabular}{|l|l|l|}
\hline Variables & $\begin{array}{l}\text { No. of } \\
\text { items }\end{array}$ & Sources of Measurement Adopted from \\
\hline $\begin{array}{l}\text { Brand Love } \\
\text { (BLV) }\end{array}$ & 10 & $\begin{array}{l}\text { Carroll \& Ahuvia (2006) ; Elaine Wallace (2014) ; Niyomsart et } \\
\text { al.,(2016); Heikki Karjaluoto (2016) ; Briliana (2017) }\end{array}$ \\
\hline Brand Loyalty(BLO) & 5 & Briliana et al. (2015) \\
\hline Brand Trust (BTS) & 9 & Azize Sahin et al.,(2011); Niyomsart et al.,(2016) \\
\hline Word-of-Mouth(WOM) & 4 & $\begin{array}{l}\text { Carroll \& Ahuvia (2006); Elaine Wallace (2014) ; Heikki Karjaluoto } \\
(2016)\end{array}$ \\
\hline
\end{tabular}

\section{Results}

\subsection{Sample Profile}

The result of the sample profile show that a majority of the respondents (45\%) were 21 to 24 years old. Approximately $49.7 \%$ of the respondents were students and employees who earned a monthly income of IDR 7.000.001 to 9.000 .000 (44.2\%). Most of them (51.3\%) have been using the GO-JEK mobile application for 5 to 6 years; they also posted information about their experience with GO-JEK on social media more than once $(96 \%)$.

\subsection{Measurement Model Results}

Table 2. PLS results of convergent validity measures

\begin{tabular}{|c|c|c|c|c|c|c|}
\hline Variabel & Items & $\begin{array}{l}\text { Outer } \\
\text { Loading }\end{array}$ & AVE & $\begin{array}{l}\text { Composite } \\
\text { Reliability }\end{array}$ & R Square & $\begin{array}{l}\text { Cronbach's } \\
\text { Alpha }\end{array}$ \\
\hline $\begin{array}{l}\text { Brand } \quad \text { Love } \\
(\mathrm{BLV})\end{array}$ & $\begin{array}{l}\text { BLV1 } \\
\text { BLV2 } \\
\text { BLV3 } \\
\text { BLV4 } \\
\text { BLV5 } \\
\text { BLV6 } \\
\text { BLV7 } \\
\text { BLV8 } \\
\text { BLV9 } \\
\text { BLV10 }\end{array}$ & $\begin{array}{l}0.892 \\
0.818 \\
0.821 \\
0.730 \\
0.753 \\
0.752 \\
0.875 \\
0.743 \\
0.784 \\
0.746\end{array}$ & 0.604 & 0.938 & --- & 0.926 \\
\hline
\end{tabular}




\begin{tabular}{|c|c|c|c|c|c|c|}
\hline $\begin{array}{ll}\text { Brand } & \text { Trust } \\
\text { (BTS) } & \end{array}$ & $\begin{array}{l}\text { BTS1 } \\
\text { BTS2 } \\
\text { BTS3 } \\
\text { BTS4 } \\
\text { BTS5 } \\
\text { BTS6 } \\
\text { BTS7 } \\
\text { BTS8 } \\
\text { BTS9 }\end{array}$ & $\begin{array}{l}0.883 \\
0.705 \\
0.798 \\
0.720 \\
0.797 \\
0.718 \\
0.732 \\
0.791 \\
0.784\end{array}$ & 0.629 & 0.910 & 0.759 & 0.888 \\
\hline $\begin{array}{l}\text { Brand Loyalty } \\
\text { (BLO) }\end{array}$ & $\begin{array}{l}\text { BLO1 } \\
\text { BLO2 } \\
\text { BLO3 } \\
\text { BLO4 } \\
\text { BLO5 }\end{array}$ & $\begin{array}{l}0.777 \\
0.778 \\
0.781 \\
0.769 \\
0.747\end{array}$ & 0.665 & 0.866 & 0.707 & 0.810 \\
\hline $\begin{array}{l}\text { Word-of Mouth } \\
\text { (WOM) }\end{array}$ & $\begin{array}{l}\text { WOM1 } \\
\text { WOM2 } \\
\text { WOM3 } \\
\text { WOM4 }\end{array}$ & $\begin{array}{l}0.874 \\
0.810 \\
0.849 \\
0.845\end{array}$ & 0.697 & 0.873 & 0.760 & 0.782 \\
\hline
\end{tabular}

Table 3. PLS Results of discriminant validity measures

\begin{tabular}{|l|l|l|l|l|}
\hline & Brand Love & Brand Loyalty & Brand Trust & Word-of-Mouth \\
\hline Brand Love & $\mathbf{0 . 8 7 7}$ & & & \\
\hline Brand Loyalty & 0.830 & $\mathbf{0 . 8 5 2}$ & & \\
\hline Brand Trust & 0.871 & 0.790 & $\mathbf{0 . 7 7 8}$ & \\
\hline Word-of Mouth & 0.783 & 0.725 & 0.728 & $\mathbf{0 . 8 3 5}$ \\
\hline
\end{tabular}

Table 4. Summary of Structural Model

\begin{tabular}{|l|lll|l|l|l|l|l|}
\hline & \multicolumn{3}{|c|}{ Path } & Beta & Standard error & t value & P values & Supported \\
\hline H1 & BLV & $\rightarrow$ & BTS & 0.885 & 0.014 & 65.362 & 0.000 & YES \\
\hline H2 & BLV & $\rightarrow$ & BLO & 0.657 & 0.070 & 9.381 & 0.000 & YES \\
\hline H3 & BLV & $\rightarrow$ & WOM & 0.347 & 0.083 & 4.160 & 0.000 & YES \\
\hline H4 & BTS & $\rightarrow$ & BLO & 0.204 & 0.073 & 2.801 & 0.000 & YES \\
\hline H5 & BTS & $\rightarrow$ & WOM & 0.353 & 0.066 & 5.372 & 0.003 & YES \\
\hline H5 & BLO & $\rightarrow$ & WOM & 0.182 & 0.074 & 2.461 & 0.007 & YES \\
\hline
\end{tabular}

\section{Discussion}

This research identifies how brand love drives brand trust, brand loyalty and word of mouth. It also investigates the relationship between brand trust, brand loyalty, and WOM in online taxi motorbike users. The findings generated in this study are consistent with the results of previous research conducted by Carroll and Ahuvia 2006; Marc, 2014; Anggraeni and Rachmanita, 2015; Niyomsart et al., 2016; Briliana, 2017; and Sabrina et al., 2017. The consistency of this study's findings with those reported in previous studies indicates that brand love is a significant variable that influences brand trust, brand loyalty and word of mouth in online taxi motorbike users.

This study identifies that brand love plays a major role in shaping brand trust. Online taxi and motorbike services connect passengers and vehicle owners (drivers) in real time using cellular technology. Thus, the passengers were impressed with the services provided because their travel needs and expectations were met. Some individuals find it difficult to use private vehicles due to high parking fees per hour and congestion, 
which sometimes makes it difficult for people to drive their vehicles. These individuals are more likely to order online transportation services. They also trust the services provided it is standardized by the company.

In addition, these findings identify that online motorbike taxi transportation companies provide various conveniences in terms of ordering, usage and payment for the taxi. Hence, customers form perceptions of service expectations that is received from several sources, such as word of mouth, past experience and advertising. Customers feel satisfied when their experience supersedes their expectations. Feelings of passion, satisfaction, and happiness result in brand love. If the expectations of consumer satisfaction are met or exceeded by the company, a repeat purchase process will occur. Thus, it can be inferred that consumer satisfaction results in consumer loyalty. Loyal consumers express their love for the brand. Brand loyalty often leads to the emergence of brand commitment, which influences the emotional and psychological bond of consumers to a product.

\section{Conclusion}

The findings generated in this study show that brand love triggers WOM advertising by customers. Most consumers use social media platforms to share and obtain information about a product. Marketing or advertising remind consumers about the function of a product or service. This often determines if users will accept the features of the products or services provided by a particular brand. Thus, e-providers of a taxi and motorbike services may use social media platforms, such as Instagram, to inform, promote and persuade potential customers to purchase their products or services. It would be necessary for future research to examine the perceptions of the user in other Indonesian regions, in order to improve the generalizability of the findings. Further, this study only explores brand love, brand trust and brand loyalty as factors determining WOM to choose an online public transport app in Jakarta, Indonesia.

\section{References}

Adilla Anggraeni and Rachmanita. (2015). Effects of Brand Love, Personality and Image on Word of Mouth: The Case of Local Fashion Brands Among Young Consumers. Proceedings of Social and Behavioral Sciences, 211, $442-447$.

Albert, Noel and D. Merunka. (2013). The Role of Brand Love in Consumer-brand Relationships. Journal of Consumer Marketing, 30(3), 258-266.

Arjun, C., Morris and Holbrook, B. (2001). The Chain of Effects From Brand Trust and Brand Affect to Brand Performance: The Role of Brand Loyalty, Journal of Marketing, 65, 81-93.

Azize Ahin Cemal Zehir Hakan Kitapçi. (2011). The Effect of Brand Experiences, Trust and Satisfaction on Building Brand Loyalty: An Empirical Research On Global Brands. Procedia Social and Behavioral Sciences, 24, $1288-1301$.

Briliana, Vita. (2017). Identifying Antecedents and Outcomes of Brand Loyalty: A Case of Apparel Brands in Social Media. Papers presented at Global Conference on Business and Economics Research (GCBER) 2017, held at Universiti Putra Malaysia, Malaysia. 14-15, 319-326.

Carroll, B. A. and Ahuvia, A. C. (2006). Some Antecedents and Outcomes of Brand Love. Marketing Letters, 17(2), 7990.

Chaudhuri, A. and Holbrook, M. (2002). Product-class Effects on Brand Commitment and Brand Outcomes: The Role of Brand Trust and Brand Affect, Journal of Brand Management, 10(1), 33-58.

Elaine Wallace, Isabel Buil, Leslie de Chernatony. (2014). Consumer engagement with self-expressive brands: brand love and WOM outcomes, Journal of Product \& Brand Management, Vol. 23 Issue: 1, pp.33-42, https://doi.org/10.1108/JPBM-06-2013-0326

Hair Jr, J. F., Hult, G. T. M., Ringle, C., \& Sarstedt, M. (2016). A primer on partial least squares structural equation modeling (PLS-SEM). Sage Publications.

Karjaluoto, H., Munnukka, J., \& Kiuru, K. (2016). Brand love and positive word of mouth: the moderating effects of experience and price. Journal of Product \& Brand Management, 25(6), 527-537.

http://www.topbrand-award.com/top-brand-survey/survey, accessed 8 Sep 2018.

Fetscherin, M. (2014). What type of relationship do we have with loved brands?. Journal of Consumer Marketing, 31(6/7), 430-440. 
Niyomsart, S and Khamwon A. (2016). Brand Love, Brand Loyalty, and Word of Mouth: A Case of Air Asia,' Conference of the International Journal of Arts and Sciences, ISSN: 1943-6114: 09(01): 263-268.

Hegner, S. M., Fenko, A., \& Teravest, A. (2017). Using the theory of planned behaviour to understand brand love. Journal of Product \& Brand Management, 26(1), 26-41.

Statistics Indonesia, https://www.bps.go.id/, accessed 8 Sep 2018. 